\title{
EFL Learning Media: Perspective on E-Learning through Google Classroom
}

\author{
Fika Megawati ${ }^{1}$, Yuli Astutik $^{2}$ \\ fikamegawati@umsida.ac.id1, yuliastutik@umsida.ac.id ${ }^{2}$ \\ Universitas Muhammadiyah Sidoarjo ${ }^{1,2}$
}

\begin{abstract}
Welcoming the fast development of technology, educators nowadays have a lot of variation in giving knowledge and practices. Intensive meetings inside the classroom need to be explored more following their habit in using gadgets for daily life activities. To get meaningful access with individual student, Google facilitates new media for teachers to conduct E-learning through Google Classroom (GC) application. This study aims to investigate how the educators and learners respond their online course activities. This may become one of the opportunities for language educators to try and make a use of the online feature in giving language written communication from shared materials and assessment. Qualitative data were collected through the responses of questionnaire survey. Applying GC to some courses gave new learning sensation. This study involved English learners who have several projects submitted online to their GC. The experiences of the students in learning through their virtual class as well as their perception for the effective use are elaborated in this study. The results implied the need of commitment for teachers to give feedback or score immediately and penalty for the late submitter.
\end{abstract}

Keywords: Google Classroom, virtual, feedback

\section{Introduction}

Google Classroom (GC), virtual class launched by Google Apps for Education (GAFE) in 2014 , becomes one of interesting parts in education issue to be reviewed and investigated nowadays and potentially in the near future. The usability is believed to be its strength. Bridging the wide need of online learning, GC has been connected to other features such as Google Drive and others. To be able to use this application, the users are required to have Gmail account. It is free of charge and no need to take a long time to comprehend how it works. This benefit gives teachers opportunities to expand the techniques of classroom management and activities [1]. Exploring self-development to be skillful to implement this tech-focus tool is required. The action can be the initial approach to the students with hightech literate skill.

In teaching practice, instruction variation needs to be developed to encourage students' motivation in learning. Implementing GC is one way conducted by educators recently. A previous study has shown the teachers' perspective on the practice [2]. In line with this, [3] has observed factors behind the use of GC, the way in using GC, the problems found during the action, and students' view after experiencing virtual classroom with the help of GC. Furthermore, [4] investigated student acceptance of GC, and the results revealed that both perceived ease of use (PEOU) and perceived usefulness (PU) affect significantly the sample of undergraduates ' behavioral intention. 
In the area of language learning, the use of GC can be investigated further. Little is known about students and teachers' view on GC for English language instruction. One of them has investigated the use of application in Listening skill [5]. The study found GC is a tool that can give positive impacts to enhance the tertiary level students' listening skill. The possibility to reach language leaning has a lot of spaces to be explored here.

Considering the high potential got from digital based instruction in the form of GC, particularly for English learning which is not broadly touched yet, this study focuses on investigating students and English instructors' perception in their first experience when using GC application.

\section{Method}

This study implemented qualitative approach. To get information about the use of GC, 29 pre-service teachers majoring in English Language Teaching at Universitas Muhammadiyah Sidoarjo, one of developing private universities in Indonesia, were purposively selected as the subjects. All of them had first experience in using GC. At the end of the odd semester of academic year 2018-2019, they were asked to express their opinion by answering open-ended online questionnaire related to the effectiveness, easiness, benefits, and weaknesses of the application based on their previous experience, followed by the ideas to make the learning process more meaningful. There were in total 10 questions distributed through the instrument. They needed only a day to return back the form. The students were asked about their opinion of the easy use of GC, the effectiveness for their language learning, the benefits, the drawbacks, lecturers' commonly selected GC feature, lecturers' feedback, and suggestion for better GC implementation.

This study also invited three English lecturers, one male and two female, to participate in strengthening the information related to GC in addition to the students' responses. Two of them have been teaching English instruction related media. The male lecturer has got Master Degree from Australia, and the other two finished their Master Degree in Indonesia. At that time, the three lecturers utilized the application for the first time in supporting their language instruction for different courses. Online questionnaire was used to collect the data. They were asked about the consideration of selecting GC, the feature they used, the way how they score the students, and their perceived usefulness when using GC. Then the information obtained from students and lecturers was analyzed and reported descriptively.

\section{Findings and Discussion}

The findings explain twofold of perspectives, from students and lecturers. From those two sides, related theories will be discussed to obtain the better understanding in the GC implementation in the context of EFL.

\subsection{Students' ${ }^{6}$ Perspectives}


The result of the students' responses from Questionnaire was summarized by using classification, especially for the effectiveness, easiness, and benefits. To make it easy to understand, the symbol checklist $(\checkmark)$ and cross $(x)$ is used for identifying the responses (see Table 1).

Table1. Students' responses on the effectiveness, easiness, and benefits of Google Classroom

\begin{tabular}{|c|c|c|c|c|c|c|c|c|c|c|c|}
\hline \multirow[b]{2}{*}{ No } & \multirow[b]{2}{*}{$\begin{array}{c}\text { Subject } \\
\text { (S) }\end{array}$} & \multicolumn{10}{|c|}{ Benefits } \\
\hline & & 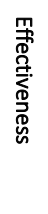 & 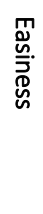 & 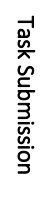 & 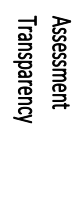 & 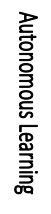 & 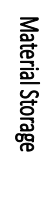 & 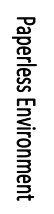 & 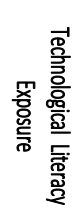 & 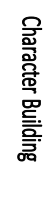 & 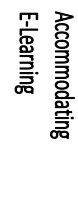 \\
\hline 1 & S 1 & $\checkmark$ & $\checkmark$ & $\checkmark$ & $\mathrm{x}$ & $\mathrm{x}$ & $\checkmark$ & $\mathrm{x}$ & $x$ & $\mathrm{x}$ & $\mathrm{x}$ \\
\hline 2 & S 2 & $\checkmark$ & $\checkmark$ & $\checkmark$ & $\mathrm{x}$ & $\mathrm{x}$ & $\mathrm{x}$ & $\mathrm{x}$ & $\mathrm{x}$ & $\mathrm{x}$ & $\mathrm{x}$ \\
\hline 3 & S 3 & $x$ & $\checkmark$ & $\checkmark$ & $\checkmark$ & $\checkmark$ & $\checkmark$ & $\checkmark$ & $\checkmark$ & $\checkmark$ & $\mathrm{x}$ \\
\hline 4 & S 4 & $\checkmark$ & $\checkmark$ & $\mathrm{x}$ & $\mathrm{x}$ & $\mathrm{x}$ & $\mathrm{x}$ & $\mathrm{x}$ & $\checkmark$ & $\mathrm{x}$ & $\mathrm{x}$ \\
\hline 5 & S 5 & $\checkmark$ & $\checkmark$ & $\checkmark$ & $\mathrm{x}$ & $\mathrm{x}$ & $\mathrm{x}$ & $\mathrm{x}$ & $\mathrm{x}$ & $\mathrm{x}$ & $\mathrm{x}$ \\
\hline 6 & S 6 & $\checkmark$ & $\checkmark$ & $\checkmark$ & $\mathrm{x}$ & $\mathrm{x}$ & $\checkmark$ & $\mathrm{x}$ & $\mathrm{x}$ & $\mathrm{x}$ & $\mathrm{x}$ \\
\hline 7 & S 7 & $\checkmark$ & $\checkmark$ & $\checkmark$ & $\mathrm{x}$ & $\mathrm{x}$ & $\mathrm{x}$ & $\checkmark$ & $\mathrm{x}$ & $\checkmark$ & $\mathrm{x}$ \\
\hline 8 & S 8 & $\checkmark$ & $\checkmark$ & $\checkmark$ & $\mathrm{x}$ & $\mathrm{x}$ & $\mathrm{x}$ & $\mathrm{x}$ & $\mathrm{x}$ & $\mathrm{x}$ & $\mathrm{x}$ \\
\hline 9 & S 9 & $\checkmark$ & $\checkmark$ & $\checkmark$ & $\mathrm{x}$ & $\mathrm{x}$ & $\mathrm{x}$ & $\mathrm{x}$ & $\mathrm{x}$ & $\mathrm{x}$ & $\mathrm{x}$ \\
\hline 10 & S 10 & $\checkmark$ & $\checkmark$ & $\checkmark$ & $\mathrm{x}$ & $\mathrm{x}$ & $\mathrm{x}$ & $\mathrm{x}$ & $\mathrm{x}$ & $\mathrm{x}$ & $\mathrm{x}$ \\
\hline 11 & S 11 & $x$ & $\checkmark$ & $\mathrm{x}$ & $\mathrm{x}$ & $\checkmark$ & $x$ & $\mathrm{x}$ & $\mathrm{x}$ & $\mathrm{x}$ & $\mathrm{x}$ \\
\hline 12 & S 12 & $\checkmark$ & $\checkmark$ & $\checkmark$ & $\mathrm{x}$ & $\mathrm{x}$ & $\mathrm{x}$ & $\mathrm{x}$ & $\mathrm{x}$ & $\mathrm{x}$ & $\mathrm{x}$ \\
\hline 13 & S 13 & $\checkmark$ & $\checkmark$ & $\mathrm{x}$ & $\mathrm{x}$ & $\mathrm{x}$ & $\mathrm{x}$ & $\mathrm{X}$ & $\mathrm{x}$ & $\mathrm{x}$ & $\mathrm{x}$ \\
\hline 14 & S 14 & $\checkmark$ & $\checkmark$ & $\checkmark$ & $\checkmark$ & $\mathrm{x}$ & $\mathrm{x}$ & $\mathrm{x}$ & $\mathrm{x}$ & $\mathrm{x}$ & $\mathrm{x}$ \\
\hline 15 & S 15 & $\checkmark$ & $\checkmark$ & $\mathrm{x}$ & $\mathrm{x}$ & $\mathrm{x}$ & $\mathrm{x}$ & $\mathrm{x}$ & $\mathrm{x}$ & $\mathrm{x}$ & $\checkmark$ \\
\hline 16 & S 16 & $\checkmark$ & $\checkmark$ & $\mathrm{x}$ & $\mathrm{x}$ & $\mathrm{x}$ & $\mathrm{x}$ & $\checkmark$ & $\mathrm{x}$ & $\mathrm{x}$ & $\mathrm{x}$ \\
\hline 17 & S 17 & $\mathrm{x}$ & $\checkmark$ & $\mathrm{x}$ & $\checkmark$ & $\mathrm{x}$ & $\mathrm{x}$ & $\mathrm{x}$ & $\mathrm{x}$ & $\mathrm{x}$ & $\mathrm{x}$ \\
\hline 18 & S 18 & $\checkmark$ & $\checkmark$ & $\checkmark$ & $\mathrm{x}$ & $\mathrm{x}$ & $\mathrm{x}$ & $\mathrm{X}$ & $\mathrm{x}$ & $\mathrm{x}$ & $\mathrm{x}$ \\
\hline 19 & S 19 & $\checkmark$ & $\checkmark$ & $\checkmark$ & $\mathrm{x}$ & $\mathrm{x}$ & $\mathrm{x}$ & $\mathrm{X}$ & $\mathrm{x}$ & $\mathrm{x}$ & $\mathrm{x}$ \\
\hline 20 & S 20 & $\checkmark$ & $\checkmark$ & $\checkmark$ & $\mathrm{x}$ & $\mathrm{x}$ & $\mathrm{x}$ & $\mathrm{x}$ & $\mathrm{x}$ & $\mathrm{x}$ & $\mathrm{x}$ \\
\hline 21 & S 21 & $\mathrm{x}$ & $\checkmark$ & $\checkmark$ & $\mathrm{x}$ & $\mathrm{x}$ & $\mathrm{x}$ & $\mathrm{x}$ & $\mathrm{x}$ & $\mathrm{x}$ & $\mathrm{x}$ \\
\hline 22 & S 22 & $\mathrm{x}$ & $\checkmark$ & $\checkmark$ & $\mathrm{x}$ & $\mathrm{x}$ & $\mathrm{x}$ & $\mathrm{x}$ & $\mathrm{x}$ & $\mathrm{x}$ & $\mathrm{x}$ \\
\hline 23 & S 23 & $\checkmark$ & $\checkmark$ & $\checkmark$ & $\mathrm{x}$ & $\mathrm{x}$ & $\mathrm{x}$ & $\mathrm{x}$ & $\mathrm{x}$ & $\mathrm{x}$ & $\mathrm{x}$ \\
\hline 24 & S 24 & $\checkmark$ & $\checkmark$ & $\checkmark$ & $\mathrm{x}$ & $\mathrm{x}$ & $\mathrm{x}$ & $\mathrm{x}$ & $\mathrm{x}$ & $\mathrm{x}$ & $\mathrm{x}$ \\
\hline 25 & S 25 & $\checkmark$ & $\checkmark$ & $\checkmark$ & $\mathrm{x}$ & $\mathrm{x}$ & $\mathrm{x}$ & $\mathrm{x}$ & $\mathrm{x}$ & $\mathrm{x}$ & $\mathrm{x}$ \\
\hline 26 & S 26 & $\checkmark$ & $\checkmark$ & $\checkmark$ & $\mathrm{x}$ & $\mathrm{x}$ & $\mathrm{x}$ & $\mathrm{x}$ & $\mathrm{x}$ & $\mathrm{x}$ & $\mathrm{x}$ \\
\hline 27 & S 27 & $\mathrm{x}$ & $\checkmark$ & $\checkmark$ & $\mathrm{x}$ & $\mathrm{x}$ & $\mathrm{x}$ & $\mathrm{x}$ & $\mathrm{x}$ & $\mathrm{x}$ & $\mathrm{x}$ \\
\hline 28 & S 28 & $\checkmark$ & $\checkmark$ & $\checkmark$ & $\mathrm{x}$ & $\mathrm{x}$ & $\mathrm{x}$ & $\mathrm{x}$ & $\mathrm{x}$ & $\mathrm{x}$ & $\mathrm{x}$ \\
\hline 29 & S 29 & $\mathrm{x}$ & $\checkmark$ & $\checkmark$ & $\mathrm{x}$ & $\mathrm{x}$ & $\mathrm{x}$ & $\mathrm{x}$ & $\mathrm{x}$ & $\mathrm{x}$ & $\mathrm{x}$ \\
\hline
\end{tabular}

Highlighting the answers for the effectiveness, the students' general positive ideas are focusing on task submission. In contrast, some students were not quite excited to this virtual learning duo to the absence of interaction between teacher and students because they used to have face to face instruction. Another view stated that this online tool is useful for learners in common, not language learners because the student felt that there was no something special to improve language skills during the process, except assignment submission. In addition, the 
students found some weaknesses in the implementation of GC in terms of health, low accessibility of internet access, possibility for cheating, and no detailed feedback.

To get more benefits, some suggestion which shown their expectation were given. First, the use of GC should be done more interactively. Since the most dominant activity is just submitting work, it appeared that less interaction between students and lecturers as well as student and student in the post of application occurred. Second, the students need more interesting use of GC. What is meant by interesting here is that the need of inserting more media or inserting another compatible application to the GC. Third, some comments suggest to have more frequent use of GC due to the fact that they got only one meeting from one of the courses they take. Fourth, improving the variation in using the feature is needed.

\subsection{English Language Educators' Perspectives}

The first thing observed from the lecturers' view is the reason why they used GC in their classes. From the educators" point of view, the consideration to take this virtual tool is diverse. First lecturer (L1) mentioned that students had already had Gmail account. The familiarity of the students to the email address opened chance to introduce GC. Furthermore, she used GC as supplementary tool to teach TEFL are Micro Teaching. It was expected to give the students variation for learning activities. The second lecturer (L2) taught Speaking, and she selected GC due to its function as a formal apps for the language assessment instead of asking the students to hand in the tasks through email. The last opinion comes from the third lecturer (L3) who taught Grammar. He admitted that the application is supporting the advance of technology in terms of online tool, and he could apply it easily. Similarly, [6] suggested teachers to use GC based on the result of the usability evaluation which indicated more benefits got from GC in the practice of blended learning.

The next question is related to their ideas on the way how they implemented GC to assist their instruction. L1 stated that this mobile-friendly tool is the place for collecting the students' assignment. In addition, this application was used to share files related to the courses. Therefore, many files can be kept here safely. Different from the first opinion, L2 and L3 mainly used GC for students' assignment submission. In line with this, GC provide new easy way in tracking students' assignment submission as opposed to the traditional technique (manually hand in) [7]. After one semester used GC, they expressed their impression by telling that $\mathrm{GC}$ is attractive digital media, and would like to use it more often in their next teaching.

Dealing with the features, the three educators agreed that assignment is the most popular choice to be used for the class. Because L1 has shared several files to the students through this medium, she explained that topic is also an interesting place to tell the students the materials related to the courses. Actually, the are many tools in the application. [5] summarized the feature into four, namely, create announcement, create assignment, create question, and reuse post. It suggests that the teachers should strengthen their technology literacy as well as skill in order to get optimal implementation of the features. It is assumed that the first experience is the place to trial and error. In addition, the three teachers have tried to use the application without any training. There was no any experience before. Thus, to avoid miscommunication between the students and the teacher during the use of the tool, assignment seemed to be the first emerging section as the favorite choice. In line with this, [8] mentions that there are three important things contributing teachers' perception, namely years of experience, grade level assignment, and subject matter. Dealing with years of experience, applying one particular tool to teach in one semester is not considered optimal, and there should be self-reflection from the teachers to get the most benefit through the development in the next use. 
The last question is about feedback. In the practice, L1 gave both written feedback and score for the assignment. It depended on the type of task. However, it was done unregularly, so it seemed that there was inconsistence to check the students' work. L2 preferred to give score, not feedback. The feedback was shared in the classroom interaction since she claimed that it was more effective for the students' improvement. L3 gave different point of view. When he implemented this tool, neither feedback nor score was given. The tool is focused on project submission. The record of the evaluation was shared in the class. Regarding the limited information dealing with feedback and the result of assessment (grade or number), teachers are actually able to learn more to develop their knowledge about integration between GS and another application. They can make rubrics as guideline for scoring. Furthermore, peer evaluation can be set for the projects [9]. It gives opportunity to edit and revise the submission in order to achieve better performance result.

The absence of strict rule in submitting the project or homework found in this study implies the tendency that the students will show low responsibility to their project. Sometimes, in one of the classes, there were some students who submitted very late or even did not want to submit if they were not reminded by on the due date. Online reminder from their Gmail account did not totally work. Thus, making agreement before we implement certain tool in the class, including GC, is strongly needed as well as the consequence. Moreover, it should be followed by the lecturers' commitment to check the work regularly to have equal interaction although it is in virtual tool.

\section{Conclusion}

To sum up, in order to obtain optimal use of GC, there should be adequate understanding of the application and its function both from teachers and students. However, in language learning there is no specific information showing that GC as the digital media contributing to the success from obtained perspectives. No matter the academic field taught through this tool as long as it can be used optimally, GC can be one of teachers ' assistance for their classes. As the initial study, there are many things should be developed by near future researchers to conduct English instruction with GC as E-learning platform. Plenty of aspects can be investigated. If the focus is still on assessment, integrating GC and BookWidgets is one of the interesting areas suggested.

Acknowledgments. The researchers would like to express their gratitude to Universitas Muhammadiyah Sidoarjo for every support given to this publication. Further, we thank the students and the lecturers who kindly gave information for completing the data in this study.

\section{References}

[1] A. Kasula, "Is Google Classroom Ready for ELL?," Word, vol. 24, no. 2, pp. 11$12,2015$. 
[2] K. A. Azhar and N. Iqbal, "Effectiveness of Google Classroom: Teachers' perceptions," Prizren Soc. Sci. J., vol. 2, no. 2, pp. 52-66, Aug. 2018.

[3] S. Iftakhar, "Google Classroom: What Works and How?," J. Educ. Soc. Sci., vol. 3, no. Feb., pp. 12-18, 2016.

[4] R. A. S. Al-Maroof and M. Al-Emran, "Students Acceptance of Google Classroom: An Exploratory Study using PLS-SEM Approach,” Int. J. Emerg. Technol. Learn., vol. 13, no. 06, pp. 112-123, May 2018.

[5] M. M. Fa. Rabbi, A. Zakaria, and M. M. Tonmoy, "Teaching Listening Skill through Google Classroom: A Study at Tertiary Level in Bangladesh,” 2018. [Online].

Available:

https://www.researchgate.net/publication/324561428_Teaching_Listening_Skill_throu gh_Google_Classroom_A_Study_at_Tertiary_Level_in_Bangladesh. [Accessed: 23-Sep2018].

[6] K. L. A. Estira, M. J. De Gusman, C. M. Cabaluna, and R. J. M. Ventayen, "Usability Evaluation of Google Classroom: Basis for the Adaptation of GSuite E-Learning Platform," Asia Pacific J. Educ. Arts Sci., vol. 5, no. 1, pp. 47-51, 2018.

[7] S. Bhat, R. Raju, A. Bikramjit, and R. D’Souza, "Leveraging E-Learning through Google Classroom: A Usability Study," J. Eng. Educ., vol. 31, no. 3, pp. 129-135, 2018.

[8] T. D. Ballew, "Teacher Perceptions of a Technology-based Google Classroom," Carson-Newman University, 2017.

[9] A. Keeler, "Peer Evaluation in Google Classroom," 2015. [Online]. Available: https://alicekeeler.com/2015/08/10/peer-evaluation-in-google-classroom/. [Accessed: 29-Sep-2018]. 